\title{
REVITALISASI PENDIDIKAN ISLAM PADA MADRASAH
}

\author{
Syamsul Aripin \\ Universitas Islam Negeri Syarif Hidayatullah Jakarta \\ J. Ir. H. Juanda No. 95 Ciputat, Tanggerang Selatan 15412 \\ Email:syamsul_aripin1981@yahoo.com
}

Abstrac: Revitalization of Islamic Education at Madrasah. Attempts to reconcile religious teachings with the modern era continue to be done in the madrasah Muslims. This is to show that Islam is not against the modern era. Because in the modern era of human life will be characterized by two tendencies that are opposed to Islam, namely; science vs. Faith and piety, vs. secularism and spiritual vs. material. Therefore, Islamic education in madrasah should also increase its role as an Islamic educational institution to respond to modernization progress at this time, for example by revitalizing its education system pro-change so as to improve the quality of learning, preparing a reliable graduate of madrasah so as to compensate the current modernization and do not miss era by not abandoning madrasah education programs that have existed since the first and match the modern era in the 21st century.

Keywords: revitalization, Islamic Education, madrasah, modern era

Abstrak: Revitalisasi Pendidikan Islam Pada Madrasah. Upaya merekosiliasi ajaran agama dengan era modern terus dilakukan kaum muslimin di madrasah. Hal ini untuk menunjukkan bahwa Islam tidak bertentangan dengan era modern. Sebab di era modern kehidupan manusia akan ditandai oleh dua kecendrungan yang saling bertentangan dengan Islam, yakni; ilmu pengetahuan vs iman takwa, ajaran vs sekulerisasi serta spiritual vs material. Untuk itu pendidikan Islam pada madrasah juga harus meningkatkan peranannya sebagai lembaga pendidikan Islam untuk merespon kemajuan modernisasi saat ini, misalnya dengan merevitalisasi sistem pendidikannya yang pro perubahan sehingga dapat meningkatkan kualitas pembelajaran, mempersiapkan lulusan madrasah yang handal sehingga dapat mengimbangi arus modernisasi yang ada dan tidak ketinggalan zaman dengan tidak meninggalkan program pendidikan madrasah yang sudah ada sejak dahulu dan cocok dengan era modern pada abad 21 ini.

Kata Kunci: Revitalisasi, Pendidikan Islam, Madrasah, Masa Modern 


\section{Pendahuluan}

Madrasah'1sebagai bentuk lain dari Pendidikan Islam yang menggunakan sistem kelas dan pembelajaran klasikal. Sejak awal berdirinya dikenal dominan mengajarkan muatan keagamaan, sehingga biasa disebut madrasah diniyah. Masa pertumbuhannya di Indonesia, jam pembelajaran di madrasah umumnya dilaksanakan sore hari. Di era 70-an madrasah dipandang setara dengan sekolah umum dengan konsekwensi kurikulumnya harus memuat seluruh mata pelajaran yang ada di sekolah umum, Di Indonesia eksistensi madrasah cukup banyak. Jumlahnya diketahui sebagai berikut :

\section{Tabel 1. Data Kuantitatif Madrasah}

\begin{tabular}{lllll}
\hline No & Jenjang & Status Negeri & Status Swasta & Jumlah \\
\hline 1 & Ibtidaiyah & 1.025 & 23.625 & 24.650 \\
2 & Tsanawiyah & 853 & 7.547 & 8.600 \\
3 & Aliyah & 57 & 2.701 & 2.758 \\
\hline
\end{tabular}

Madrasah merupakan bentuk lembaga pendidikan Islam modern, sebab pendidikan Islam madrasah merupakan pendidikan yang sudah menyerap sistem pendidikan modern, baik pengelolaannya maupun proses pembelajaran serta materi pelajaran yang bukan saja belajar agama tetapi juga belajar ilmu-ilmu umum. Hal itu disebabkan bahwa munculnya model pendidikan madrasah

${ }^{1}$ Kata madrasah dalam bahasa Arab berarti tempat atau wahana untuk mengenyam proses pembelajaran. Dalam bahasa Indonesia madrasah disebut dengan sekolah yang berarti bangunan atau lembaga untuk belajar dan memberi pengajaran.Karenanya, istilah madrasah tidak hanya diartikan sekolah dalam arti sempit, tetapi juga bisa dimaknai rumah, istana, kuttab, perpustakaan, surau, masjid, dan lain-lain, bahkan seorang ibu juga bisa dikatakan madrasah pemula. Sementara Karel A. steenbrik justru membedakan antara madrasah dan sekolah-sekolah, dia beralasan bahwa antara madrasah dan sekolah mempunyai ciri yang berbeda.Madrasah mulai didirikan dan berkembang pada abad ke $5 \mathrm{H}$ atau abad ke-10 atau ke-11 M. Lihat Abuddin Nata, Sejarah Pendidikan Islam Pada Periode Klasik dan Pertengahan (Jakarta: PT. Raja Grafindo Persada, 2004),h. 50, Lihat juga suwito, sejarah sosial pendidikan Islam (Kencana, Jakarta 2005), h.214, Lihat juga Hasbullah, Sejarah Pendidikan Islam di Indonesia (Jakarta: PT. RajaGrafindo Persada, 2001), h.160. 
karena adanya persentuhan atau kontak langsung dengan model pendidikan Barat melalui Kyai dan Ulama yang pernah belajar di Timur Tengah. Pendidikan Islam madrasah telah ada pada awal-awal kemerdekaan yang didalam kurikulum pembelajarannya, di samping memberikan mata pelajaran agama juga mata pelajaran umum.

Sedang Madrasah di Indonesia merupakan fenomena modern yang tumbuh dan berkembang sebagai bagian dari proses pembaharuan pendidikan Islam di negeri ini. Meskipun secara kelembagaan sekolah, kandungan pendidikan madrasah terutama pada masa awal perkembangannya mengacu pada ilmu-ilmu keislaman.

Meski Madrasah merupakan lembaga pendidikan Islam modern, Namun dalam kenyataannya menghadapi era modern Madrasah masih menghadapi beberapa persoalan antara lain masalah kesetaraan (equality), pemerataan (equity), mutu (quality), kurikulum (curriculum), sarana pendidikan (facility) dan pengelolaan (governance) sehingga perlu revitalisasi. Berikut pembahasannya.

\section{Modernisasi dan Pendidikan.}

Modernisasi ${ }^{2}$ yang terjadi sekarang ini telah merambah berbagai bidang kehidupan umat manusia dan memberikan perubahan terhadap dunia pendidikan sehingga pendidikan mengalami modernisasi. Modernisasi semacam ini memang tidak bisa dihindarkan, bahkan merupakan tuntutan. Tuntutan perubahan ini bukan saja berasal dari pengaruh perkembangan ilmu pengetahuan

${ }^{2}$ Modernisasi adalah proses sosial. Berasal dari kata induk "modern" yang berarti gaya baru maka modernisasi berarti proses pergantian dari gaya lama menjadi gaya baru. Di dalam proses itu terjadi perubahan. Khususnya perubahan yang diusahakan dengan sadar oleh manusia atau masyarakat. Oleh karena diusahakan dengan sadar maka sudah semestinya modernisasi tidak hanya mengarah kepada gaya baru, akan tetapi gaya baru itu diharapkan lebih menyenangkan dan lebih memuaskan manusia dan masyarakat daripada gaya lama yang digantikannya. 
dan teknologi (IPTEK) serta globalisasi, ataupun tuntutan pembangunan nasional, melainkan tuntutan masyarakat. ${ }^{3}$

Modernisasi pendidikan yang terjadi di dunia Islam tidak lebih dari respon positif para modernis Muslim terhadap ketertinggalan umat Islam dari kemajuan Barat modern. Modernisasi sendiri merupakan sebuah gerakan Islam yang mencakup gerakan-gerakan "pembaruan Islam". ${ }_{4}$ Menurut Fazlur Rahman modernisasi di dunia Islam terjadi pada abad ke sembilan belas yang digerakkan oleh elit penguasa (birokrat) ${ }^{5}$ dengan tujuan menciptakan keseimbangan (equilibrium) antara masyarakat Barat dan Islam. Untuk terwujudnya hal tersebut masyarakat Muslim harus belajar dan mengadopsi kemajuan-kemajuan yang dicapai masyarakat Barat. ${ }^{6}$

Salah satu karakter penting gerakan modernisasi Islam menurut Charles Kurzman adalah muncul dan menguatnya kesadaran untuk mengadopsi nilai-nilai modern dikalangan kaum Muslim dimana Nilai-nilai modern yang dimaksud disini antara lain rasionalitas, sains, konstitusi, konsep-konsep baru tentang nilai-nilai egalitarian dan sebagainya.7 Sehingga menurut Muhammad Khalid Masud ketika lembaga pendidikan melakukan modernisasi dengan mengambil elemen-elemen modern Barat, termasuk mengajarkan sains modern, maka kesadaran akan identitas Islam-lebih sempit lagi dan ideologi keagamaan Islam yang mereka anut menjadi agenda yang mengemuka. ${ }^{8}$

${ }^{3}$ Peraturan Pembinaan Madrasah dalam Rangka Otonomi Daerah, (Depag RI : Dirjen Pembinaan Kelembagaan Agama Islam, 2001), h. 1.

${ }^{4}$ John L. Esposito (ed), The Oxford Encyclopedia of the Modern World, (London : Oxford University Press, 1995), Vol. 2, h. 242.

5 Seperti halnya Napoleon Bornaparte yang mendarat di Mesir tahun 1789. Sultan Mahmud II di Turki pada periode kerajaan Turki Utsmani. Kecuali Iran, modernisasi digerakkan oleh elit ulama (mullah) dan kaum intelektual, sementara para penguasa sendiri lebih memilih status quo (kemapanan), tidak menginginkan perubahan dalam bentuk apapun konservatif (modernisasi, reformasi).

${ }^{6}$ John L. Esposito (ed), The Oxford Encyclopedia of the Modern World, h. 118.

${ }^{7}$ Charles Kurzman (ed), Modernist Islam 1840-1940; A Source Book (Oxford: Oxford University Press, 2002), h. 4-5.

${ }^{8}$ Muhammad Khalid Masud, "Religius Identity and Mass Education", dalam Johan H. Meuleman (ed), Islam in the Era Globalization, Muslim Attitudes Towards Modernity and Identity (Jakarta : INIS, 2001), h. 233-245. 
Sebaliknya, untuk modernisasi pendidikan di Indonesia, Harun Ashrohah mengatakan pada permulaan abad ke-20 masyarakat Islam Indonesia telah mengalami beberapa perubahan baik dalam bentuk kebangkitan agama, perubahan, maupun pencerahan yang diakibatkan adalah dorongan untuk melawan penjajah bangsa Belanda. Sebab tidak mungkin bangsa Indonesia harus mempertahankan segala aktivitas dengan cara tradisional untuk melawan kekuatan-kekuatan kolonialisme Belanda. ${ }^{9}$

Menurut Nurcholish Madjid, modernisasi pendidikan yang terjadi di Indonesia tidak bersumber dari kalangan Muslim sendiri tetapi justru diperkenalkan oleh pemerintah kolonial Belanda. ${ }^{0 S}$ Sebaliknya Azyumardi Azra berpendapat bahwa modernisasi di Indonesia berasal dari para pelajar Indonesia yang pulang dari Mekkah yang berhasil melakukan intensifikasi Islam, maka para pelajar tersebut melakukan modernisasi di Indonesia dengan pembentukan lembaga-lembaga pendidikan modern yang diadopsi dari sistem pendidikan Belanda dengan mengambil elemenelemen modern Barat. ${ }^{11}$ Menurutnya, pemikiran dan kelembagaan Islam termasuk pendidikan Islam Madrasah harus diperbaharui agar sesuai dengan kerangka kemodernan dalam rangka memberdayakan masyarakat Muslim menghadapi kemajuan dan tantangan dunia modern. ${ }^{12}$

Pola pemikiran dan kelembagaan madrasah yang modern dengan aktivitas keagamaan, akan mewujudkan siswa yang berwawasan ilmu pengetahuan dengan dasar-dasar keagamaan yang kuat sehingga siswa siap menghadapi tantangan dunia global dengan tetap menjaga nilai-nilai religinya.

\footnotetext{
${ }^{9}$ Harun Ashrohah, Sejarah Pendidikan Islam, (Jakarta : PT. Logos Wacana Ilmu, 2001), Cet. Ke-2, h. 154-155.

${ }^{10}$ Nurchlish Madjid, Bilik-Bilik Pesantren Sebuah Potret Perjalanan, (Jakarta : Paramadina, 1997), Cet. Ke-1, h. xii.

${ }^{11}$ Muhammad Khalid Masud, "Religius Identity and Mass Education", dalam Johan H. Meuleman (ed), Islam in the Era Globalization, Muslim Attitudes Towards Modernity and Identity, h. 245.

${ }_{12}$ Azyumardi Azra, Modernisasi Pendidikan Islam dan Epistemologi Ilmu, Makalah pada peringatan 70 tahun Pondok Modern Gontor, 31 Agustus 1996.
} 
Pemrakarsa pertama modernisasi pendidikan di Indonesia dalam hal ini menurut Deliar Noer adalah organisasi-organisasi modernis Islam seperti Jami'at al-Khair, al-Irsyad, Muhammadiyah, dan lainlain. ${ }^{13}$ Sedangkan tokoh-tokoh modernisasi di Indonesia antara lain Syekh Ahmad Khatib, Syekh Taher Jalaluddin, Syeh Muhammad Djamil Djambek, Haji Rasul, dan Abdullah Ahmad. ${ }^{14}$

\section{Pendidikan Islam dan Modernisasi}

Diskursus mengenai modernisasi sebagaimana yang sedang penulis bahas ini menimbulkan tanggapan yang berbeda-beda. Sebagian kalangan tertentu merasa bahwa modernisasi merupakan ancamam bagi eksistensi kebudayaan lokal tertentu, mengingat modernisasi meniscayakan proses globalisasi yang menganggap bahwa dunia sebagai one world-one globe sehingga menghancurkan sekat-sekat pembeda yang ada di dunia ini. Hal inilah yang menurut Nurcholis Madjid perlu diwaspadai dalam rangka melestarikan (mempertahankan) keberagamaan manusia. Menurut Nurcholis Madjid modernisasi sering dipahami sebagai suatu proses perubahan sosial, yaitu perubahan susunan kemasyarakatan dari satu sistem sosial praindustrial (misal agraris) ke sistem sosial industrial. Kadangkadang juga disejajarkan dengan perubahan dari masyarakat pramodern ke masyarakat modern. Sehingga dalam konteks keagamaan menurutnya kehidupan industrial (yang menjadi ciri modern) dapat menimbulkan efek negatif dan sekaligus menyimpan kandungan makna yang positif. ${ }^{15}$

${ }^{13}$ Azyumardi Azra, Esei-esei Intelektual Islam, (Jakarta : PT. Logos Wacana Ilmu, 1998), Cet. Ke-1, h. 90.

${ }^{14}$ Deliar Noer, Gerakan Modern Islam di Indonesia 1990-1942, (Jakarta : LPE3S, 1980), h. 5 .

${ }^{15}$ Nurcholis Madjid, Masyarakat Religius dan Dinamika Industrialisasi dalam Islam. Kemodernan dan keindonesiaan, (Bandung : Mizan, 1987), h. 141-142. 
Di era modern pendidikan agama Islam dan lembaga pendidikan seperti madrasah menurut Suparman Ibrahim Abdullah dituntut untuk dapat memberikan jawaban atas berbagai problema yang kini dihadapi seluruh umat manusia, kehidupan masyarakat yang terus berubah dan berkembang berdampak pada pola penganutan keagamaan yang lebih rasional dan fungsional. Kemajuan dunia ilmu pengetahuan dan teknologi telah melahirkan fasilitas kehidupan dan sekaligus sistem nilai baru yang menjanjikan. Tuntutan masyarakat akan profesionalisme semakin berkembang dalam berbagai sektor kehidupan. Otoritas ulama dalam bidang keagamaan berhadapan dengan aneka keahlian masyarakat dalam bidang-bidang lain yang lebih pragmatis. Dalam waktu yang bersamaan, perkembangan telah memudahkan pengetahuan akses masyarakat termasuk ilmu-ilmu keagamaan, yang luas dan beragama. Upaya merekonsiliasikan ajaran-ajaran agama di madrasah dengan nilai-nilai pragmatis yang berbasis ilmu pengetahuan dan teknologi menjadi agenda utama kaum Muslimin sejak awal abad 20. Tujuan pokok dari usaha ini adalah menunjukkan kompitibilitas ajaran Islam yang ada di madrasah terhadap perubahan peradaban modern di satu sisi diupayakan penyegaran dan pembaharuan pemahaman ajaran agama sejalan dengan perkembangan aktual, dan di sisi lain dilakukan langkah spiritualisasi masyarakat modern agar tidak mengalami kehampaan moral dan mental secara terus menerus. ${ }^{16}$

Upaya ini bisa dilakukan sebab menurut Leonard Binder pendidikan agama Islam di madrasah dan era modern bisa sesuai sebab nilai-nilai Islam sehingga tidak sedikitpun bertentangan dengan peradaban modern. Oleh karena itu, umat Islam yang ada dilingkungan madrasah tanpa harus meninggalkan keyakinannya terhadap ajaran Islam dapat memasuki kemajuan yang telah

\footnotetext{
${ }^{16}$ Suparman Ibrahim Abdullah. Ma'had Aly, Profil Pendidikan Tinggi Pondok Pesantren di Indonesia, (Yogyakarta : RDI Indonesia), h. 48.
} 
diperoleh peradaban modern.17 Hal senada dikemukakan Abdurrahman Wahid yang mengatakan antara modernisasi dan agama adalah menyatu, menurutnya andaikata modernisasi dilepaskan dari agama maka modernisasi akan tumbuh secara bebas nilai (free of value) dan kalau ini terjadi, maka akan meruntuhkan nilai-nilai agama yang sudah ditetapkan agama. ${ }^{18}$ Sebab saat ilmu pengetahuan dan teknologi berkembang pesat serta disaat filsafat hidup manusia modern mengalami krisis keagamaan dan saat perdagangan bebas dunia sudah berjalan, maka posisi dan keberadaan pendidikan agama di madrasah tampak makin dibutuhkan. ${ }^{19}$ Bahkan di masa modern agama diharapkan dapat memberikan arahan dan perspektif baru, sehingga kehadiran agama terasa manfaatnya oleh penganut agama.

\section{Bentuk Tantangan Pendidikan Islam Pada Madrasah di Masa Modern}

Arus modernisasi yang telah bergerak begitu cepat dan pesat telah membawa perubahan di berbagai bidang kehidupan manusia. Akibatnya umat Islam sebagai bagian dari komunitas sosial justru turut terpengaruh oleh berbagai perubahan tersebut. Modernisasi dan perkembangan zaman telah menghasilkan ilmu pengetahuan dan teknologi canggih dengan berbagai dampak positif sekaligus negatif. Nilai positif dari modernisasi dapat terlihat dari apa yang dianggap gaib dan tidak mungkin di masa silam menjadi nyata dan fakta dimasa kini. Sedangkan ekses negatifnya terlihat ketika ilmu pengetahuan dan teknologi diper-Tuhan-kan. Hal ini menurut Suadi

\footnotetext{
h. 221.

${ }^{18}$ Abdurrahman Wahid, Agama dan Modernisasi adalah Satu", dalam majalah Komunikasi Ekaprasetia Pancakarsa, No. 40/tahun VI/1985, h. 47.

${ }^{19}$ Rahardjo, Madrasah Sebagai The Centre Of Excellence, Diakses Lewat Internet, Pada Tanggal 23 Juli 2008.
}

${ }^{17}$ Leonard Binder, Islamic Liberalism, (Chicago : The Universirty of Chicago Press, 1988), 
Putro telah memunculkan berbagai problema-problema kompleks yang pada hakekatnya merupakan suatu tantangan besar yang harus dihadapi dan ditanggulangi secara efektif dan efesien. ${ }^{20}$ Mastuhu mengungkapkan keberhasilan suatu pembangunan termasuk bidang pendidikan selalu disertai dengan tantangan-tantangan baru sekaligus dampak negatifnya. ${ }^{21}$ Menurutnya kehidupan manusia di era modern akan ditandai oleh dua kecendrungan yang saling bertentangan atau berlawanan dengan Islam. ${ }^{22}$ Bahkan Nurcholish Madjid menambahkan bahwa di era modern bentuk hubungan dinamis antara religiusitas dan modernisasi merupakan suatu persoalan yang banyak menimbulkan kontroversi yang menurutnya akan terjadi proses yang sifatnya saling menggusur antara proses modernisasi dengan agama. ${ }^{23}$ Untuk lebih jelasnya berikut ini penulis kemukakan beberapa bentuk tantangan era modern yang dihadapi pendidikan agama Islam di Madrasah.

\section{Iptek Vs Imtak}

Ilmu pengetahuan dan teknologi menurut Muhaimin pada dasarnya suatu kebanggaan yang dicita-citakan oleh setiap orang. Temuan iptek telah menyebarkan hasil yang membawa kemajuan, dan dampaknya terasa bagi kehidupan seluruh umat manusia. Semua hasil temuan iptek di satu sisi harus diakui telah secara nyata mempengaruhi bahkan memperbaiki taraf dan mutu hidup

${ }^{20}$ Suadi Putro, Muhammad Arkoun, Tentang Islam dan Modernitas, (Jakarta : Paramadina, 1998), Cet. Ke-1, h. 46.

${ }^{21}$ Mastuhu, Memberdayakan Pendidikan Islam, (Jakarta : Logos Wacana Ilmu, 1999), h. xi.

22 Tantangan (challenge) berasal dari kata dasar "tantang" yang mendapat imbuhan "an”. Dalam Kamus Bahasa Indonesia, tantangan diartikan dengan hal atau obyek yang menggugah tekad untuk meningkatkan kemampuan untuk mengatasi masalah, hal atau objek yang perlu ditanggulangi. (Lihat: Tim P3B, Kamus Besar Bahasa Indonesia, Jakarta : Balai Pustaka, 1999, Cet. Ke-10, h. 1008).

${ }^{23}$ Abdurrahman Wahid, Agama dan Modernisasi adalah Satu”..., h. 47. 
manusia $^{24}$ namun disisi lain, ketergantungan kepada sains dan teknologi (IPTEK) yang berlebihan tersebut akan dapat menjadikan destruksi lingkungan dan politik totaliter.

Menurut Eti Rochaety kemajuan teknologi yang tidak dapat dibendung lagi, tidak hanya berdampak pada dunia pendidikan saja, melainkan juga merambah pada nilai-nilai budaya dimasyarakat, misalnya saja budaya berpakaian (fashion).25Produk temuan dan kemajuan iptek telah mempengaruhi bangunan kebudayaan dan gaya hidup manusia sehingga akan mempengaruhi nilai, sikap, atau tingkah laku kehidupan individu dan masyarakat yang akan mengakibatkan sebagian manusia modern terjauh dari nilai-nilai Islam dan juga nilai-nilai kemanusiaan sehingga akan mengalami krisis nilai-nilai spiritualitas. ${ }^{26}$ Dimana Harun Nasution mengatakan bahwa revolusi kemajuan ilmu pengetahuan dan teknologi (IPTEK) itu membawa problem-problem yang sulit dapat dicari pemecahannya dewasa ini. ${ }^{27}$

Dalam masyarakat modern Nurcholish Madjid mengatakan, masyarakat sering rentan terhadap depersonalisasi dan dehumanisasi. Akibatnya ia tidak lagi mengenali dirinya sendiri dan makna hidupnya atau alienasi. ${ }^{28}$ Karena itu, masalah yang perlu segera mendapat jawaban, terutama dari pendidikan Islam di madrasah adalah mampukah kegiatan pendidikan Islam di madrasah berdialog dan berinteraksi dengan perkembangan zaman modern yang

${ }^{24}$ Muhaimin, et.al., Paradigma Pendidikan Islam Upaya Mengefektifkan Pendidikan Agama Islam di Sekolah, (Bandung: PT. Remaja Rosdakarya, 2004), h. 86.

${ }^{25}$ Eti Rochaety, Pontjorini Rahayuningsih Prima Gusti Yanti, Sistem Informasi Manajemen Pendidikan, (Jakarta : Bumi Aksara, 2006), Cet. Ke-11, h. 64.

${ }^{26}$ Tim Perumus Fakultas Teknik Universitas Muhammadiyah Jakarta, Al-Islam dan IPTEK, (Jakarta, Universitas Muhammadiyah Jakarta, 1998), h. 91.

27 Harun Nasution, Perlunya Menghidupkan Kembali Pendidikan Moral, (Jakarta : Konsorsium Pendidikan Agama di Perguruan Tinggi Umum, DIKTI Depdikbud, 1995), h. 9

28 Nurcholis Madjid, Peranan Agama dalam Kehidupan Modern, dalam Islam, Kemodernan, Keindonesiaan, h. 124. 
ditandai dengan kemajuan iptek dan informasi, dan mampukah mengatasi dampak negatif dari kemajuan tersebut. ${ }^{29}$

\section{Ajaran Islam Vs Sekulerisasi}

Ajaran Islam yang selama ini mengatur seluruh kehidupan manusia di dunia ini di era modern menghadapi tantangan yang cukup berat yakni sekulerisasi. ${ }^{30}$ Sekulerisasi merupakan faham yang ingin memisahkan urusan dunia dengan urusan akhirat. Sekulerisasi mengajarkan semua urusan kehidupan di dunia ini terlepas dari ajaran agama sebab agama dan kehidupan berbeda. Hal ini bertolak belakang dengan prinsip ajaran Islam yang selama ini menjadi rahmat bagi seluruh alam. Islam bukan hanya sebatas agama yang memuat masalah hubungan manusia terhadap tuhannya saja melainkan Islam juga mengajarkan bahkan mengatur hubungan manusia dengan sesama manusia dan hubungan manusia dengan alam. Sebab ajaran Islam itu holistik (kaffah) mencakup seluruh aspek kehidupan; ekonomi, sosial, budaya, politik, agama, seni dan lainlain. Dalam kalimat yang padat Muhammad Abdul Karim Khayyal mengatakan :

"Islam adalah aturan yang lengkap meliputi seluruh aspek kehidupan, Islam adalah negara dan bangsa atau pemerintahan dan masyarakat juga moral dan kekuasaan. Islam adalah rahmat dan keadilan, peradaban dan undang-undang, ilmu pengetahuan dan

29 Muhaimin, et.al., Paradigma Pendidikan Islam Upaya Mengefektifkan Pendidikan Agama Islam di Sekolah, h. 86.

${ }^{30}$ Dalam kamus bahasa Indonesia disebutkan bahwa" sekuler" artinya "percaya kepada dunia". Sekulerisasi adalah "ideologi ateis atau agnostik yang mengeyampingkan kepercayaan dan nilai-nilai religius dan menjelaskan segala sesuatu melulu dalam lingkup dunia ini.(Lihat Departemen Pendidikan dan Kebudayaan, Kamus Besar Bahasa Indonesia, Jakarta : Balai Pustaka, 1988, h. 291). 
hukum, kekayaan materi, kerja dan harta, jihad dan dakwah, kekuatan senjata dan konsep." 31

Di Indonesia pengaruh sekulerisasi menurut Syed Muhammad Naquib Al-Attas sangat mencolok apabila dibandingkan dengan negara Islam lainnya di dunia ${ }^{32}$ sehingga menurut M. Umar Chapra hal ini menyebabkan orang modern berpandangan sekuler. ${ }^{33}$ Menurut Fazlur Rahman hal ini diakibatkan semakin kuatnya pengaruh Eropa terhadap dunia Islam melalui kolonialisme dan imprialisme sehingga sekulerisasi juga mulai tertanam dan tumbuh di dunia Islam. Penyebab sekulerisasi sendiri menurut Fazlur Rahman adalah kemandegan pemikiran Islam yang mendorong masyarakat Muslim untuk mengambil pemikiran yang berkembang di Barat tanpa mengikuti penjelasan filosofis yang berada dibelakangnya. ${ }^{34}$ Sebaliknya Mohammad Arkun berpendapat sekulerisasi telah ada dan diajarkan dalam Alquran dan kehidupan Nabi Muhammad Saw di Madinah.

Adapun ciri sekulerisasi menurut Dale F Eickelman dan J Piscatori adalah adanya pandangan bahwa masalah agama adalah masalah tersendiri terlepas dari aspek lain yang bersifat keduniaan. ${ }^{35}$ Demikian juga pandangan yang memisahkan agama dari politik,36

${ }^{31}$ Muhammad Abdul Karîm Khayyal, Syarh wâ Tahlîl Ushûl al-Isyrîn, (Dâr al-Dakwah, Iskandariâh, Cairo), tt. h. 35-36.

${ }^{32}$ Syed Muhammad Naquib Al-Attas, Islam and Seculerisme, (Kuala Lumpur : Muslim Youth Movement of Malaysia, 1979), h. 11.

${ }^{33}$ M. Umar Chapra, Islam dan Tantangan Ekonomi Islamisasi Ekonomi Kontemporer. (Surabaya : Risalah Gusti, 1999), Cet. Ke-1, h.1.

${ }^{34}$ Fazlur Rahman, Islam and Modernity, Transformation of an Intellectual Tradition (Chicago: The University of Chicago Press, 1982). h. 43.

${ }^{35}$ Pemisahan dunia dan akhirat (agama). Dengan potensi yang dimilikinya, manusia diberi wewenang penuh untuk mengatur kehidupan dunia, sedangkan Allah adalah penguasa akhirat. Manusia mengatur kehidupannya tersendiri di dunia, dan agama mengatur kehidupan umat manusia di akhirat. Dengan kata lain, terdapat pemisahan antara wewenang ilahi dan wewenang manusia. (Lihat Dale F Eickelman dan J Piscatori, Muslim Politic, Terj. Rafik Suhudi, Ekspresi Politik Muslim, Bandung : Mizan, 1998, Cet. Ke-1, h. 60).

${ }^{36}$ Pemisahan antara agama dan negara (politik). Terdapat tiga paradigma tentang hubungan agama dan negara yaitu integralitas simbiotik dan sekuleristik. (Lihat M. Din Syamsudin, Etika Agama dalam Membangun Masyarakat Madani, h. 58-61). Paradigma integralistik menempatkan 
sosial, ekonomi dan budaya adalah merupakan bagian dari sekulerisasi ${ }^{37}$ dimana masing-masing terpisah dan berdiri sendiri.

\section{Spiritual Vs Material}

Menurut M. Noor Syam dewasa ini budaya modern telah mengalami krisis. ${ }^{38}$ Kebudayaan modern yang berintikan liberalisasi, rasionalisasi efesiensi menurut Azyumardi Azra perubahan ini secara konsisten terus melakukan proses pendangkalan kehidupan spiritual. Liberalisasi yang terjadi pada seluruh aspek kehidupan tak lain adalah proses desakralisasi dan de-spiritualisasi tata nilai kehidupan. Dalam proses semacam itu, agama yang sarat dengan nilai-nilai sakral dan spiritual perlahan tapi pasti tergusur dari berbagai aspek kehidupan masyarakat. Terkadang agama dipandang tidak relevan dan signifikan lagi dalam kehidupan. Akibatnya, sebagaimana terlihat pada gejala umum masyarakat modern. Kehidupan rohani di era modern semakin kering dan dangkal. ${ }^{39}$

Dalam proses modernisasi yang sedang terjadi di madrasah ini, maka menurut Nasichah hal ini seringkali mengagungkan nilai-nilai yang bersifat materi dan anti rohani, dan mengabaikan nilai-nilai spiritual, benturan-benturan antara nilai-nilai materi dan unsur-

agama dan negara secara integral. Agama bersifat kaffah dan syamil (menyeluruh dan lengkap) (Lihat QS Al-Baqarah (2) : 208). Negara adalah institusi politik dan keagamaan. Pemerintahan negara diselenggarakan atas dasar kedaulatan ilahi. Paradigma simbiotik memandang bahwa ajaran agama dan negara berhubungan secara timbal balik. Agama membutuhkan negara sebagai sarana penyebaran ajaran Islam dan negara membutuhkan agama, sebagai landasan etika dan moral. Paradigma sekulerisasi menolak paradigma integralistik dan simbiotik. Paradigma sekulerisasi memisahkan hubungan agama dan negara, dan menolak keras pendasaran negara dan agama.

${ }^{37}$ Pemisahan antara yang sakral-spiritual dengan yang profan dan temporal. Yang sakralspiritual bersifat suci ruhaniah sebagai hasil dari konsep langit yang ideal. Sedangkan yang profan dan temporal adalah sesuatu yang baru dan bersifat sementara, karena produk bumi (manusia). Dalam pandangan ini, segala sesuatu yang ada di alam ini, termasuk ajaran agama yang dipraktekkan dan teks kitab suci adalah sesuatu yang profan, temporal.

${ }^{38}$ M. Noor Syam, Filsafat Pendidikan dan Dasar Filsafat Pancasila, (Surabaya : Usaha Nasional, 1988), h. 340.

${ }^{39}$ Azyumardi Azra, Esei-esei Intelektual Muslim Pendidikan Islam, h. 100. 
unsur rohani dalam alam modern, sama halnya dengan persoalan tradisi dan modernitas. Benturan kedua nilai tersebut, secara langsung memberikan gambaran bagi sikap hidup suatu komunitas pada zaman tertentu. 40

Menurut Tarmidzi Tahir modernisasi yang sedang berlangsung ini telah tumbuh dan berkembang dan merubah pendapatan masyarakat menengah menuju masyarakat industri. Perubahan yang terjadi terbukti tidak hanya bersifat material semata, namun sebaliknya juga menyeret perubahan pada norma dan nilai sekarang ini yang dikemas dalam slogan indah seperti demokratisasi, keterbukaan, dan hak asasi manusia. ${ }^{41}$ Kondisi ini menurut Husni Rahim telah membuka dampak krisis spiritual dan kepribadian, sehingga memunculkan juga kesenjangan dan kekerasan sosial.42

Salah satu ciri kehidupan sebagian masyarakat modern dewasa ini menurut Hasan Bakti Nasution adalah berkembangnya kecendrungan pola sikap hidup material. Material sendiri berasal dari kata "materi" yaitu benda, sedangkan aliran yang menganut paham ini disebut "materialisme" yang dianut oleh aliran materialisme ini diantaranya adalah anggapan bahwa perubahan kebudayaan dan kehidupan manusia terjadi disebabkan oleh keadaan sosial, sedangkan rohani hanya pemunculan (margentisme) dari kondisi sosial ekonomi masyarakat. ${ }^{43}$

\section{Revitalisasi Model Pendidikan Madrasah di Masa Modern}

${ }^{40}$ Nasichah, Da'wah Pada Masyarakat Modern Problem Kehampaan Spiritual, (Jakarta : Da'wah : Jurnal Kajian Da'wah dan Budaya), Vol X No 2. Desember 2003, h. 4.

${ }^{41}$ Tarmidzi Tahir, Umat Islam dan Tantangan Dunia Modern, (Center For Moderate Muslim Indonesia), Diakses Lewat Internet Pada Tanggal 23 Juli 2008.

${ }^{42}$ Husni Rahim, Arah Baru Pendidikan Islam di Indonesia, (Jakarta : Logos Wacana Ilmu, 2001), h. 129.

${ }^{43}$ Hasan Bakti Nasution, Filsafat Umum, (Jakarta : Gaya Media Pratama, 2001), h. 179. 
Hal yang dapat dilakukan oleh pihak madrasah untuk mempersiapkan siswanya di masa modern adalah dengan merevitalisasi sistem pendidikannya yang tidak pro perubahan kemudian mengganti atau mengakomodasi sistem pendidikannya yang sejalan dengan tuntutan perubahan, Upaya ini menurut Indra Hasbi dapat dilakukan pengelola madrasah dengan memperhatikan dan meningkatkan kemampuannya siswa dalam bidang bahasa, baik bahasa Arab maupun Inggris; penguasaan bahasa bagi pencari kerja era ini menjadi syarat mutlak. Juga penguasaan skill tertentu yang dibutuhkan dunia kerja. Idealnya, setiap madrasah memiliki laboratorium bahasa, juga memiliki sarana dan prasarana untuk meningkatkan skill siswa baik dalam bidang perbengkelan, jahitmenjahit. Untuk mengembangkan hal itu perlu pula madrasah melakukan kerjasama dengan lembaga keuangan atau lembaga teknis lainnya. Siswa madrasah dapat pula dipersiapkan wawasan dan mentalnya agar memiliki mental kewirausahaan melalui pembinaan perkoperasian atau bentuk lainnya.

Senada dengan Indra Hasbi, Qomar juga berpendapat berbeda dengan pesantren, Madrasah merupakan lembaga pendidikan yang lebih modern dari sudut metodologi dan kurikulum pengajarannya. Oleh sebab itu Madrasah dituntut melakukan perubahan-perubahan strategis dalam bidang manajemen. Semua ini tentu saja memerlukan manajemen civitas Madrasah atau Manajemen Berbasis Sekolah (MBS) dengan berpedoman pada Fungsi-fungsi manajemen seperti planning (perencanaan), orgnising (pengorganisasian), actuating (pelaksanaan), controlling (pengawasan), dan evaluating (penilaian) serta suvervising (perbaikan) dalam kegiatan pendidikannya. ${ }^{4}$

${ }^{44}$ Mujamil Qomar, Pesantren dan Transformasi Metodologi Menuju Demokratisasi Institusi (Jakarta : Eralngga, tt), h.95. 
Sedang masalah penting revitalisasi pendidikan madrasah yaitu dalam kurikulumnya diperlukan penyatuan antara ilmu agama dan ilmu umum. Dalam mata pelajaran yang diberikan ke siswa; materi ilmu agama sudah terintegrasi dalam ilmu umum. Untuk pengembangan materi lebih dalam, mereka dianjurkan mendalami berbagai literatur lainnya. Ilmu-ilmu yang sudah terintegratif itu akan semakin memperkuat keyakinan mereka tentang tauhid atau keesaan Allah, dan juga dapat mempengaruhi moralitas siswa dalam bentuk pengalaman sehari-hari di sekolah dan di rumah. Sebab selama ini materi pendidikan di pandang belum membangun sikap kritis, masih terbatas pada masalah keagamaan, serta tidak memiliki kepedulian terhadap perkembangan ilmu-ilmu umum, baik ilmuilmu sosial maupun ilmu alam. Padahal Rosenblith dan Bailey ${ }^{45}$ mengatakan pendidikan agama yang dilakukan dengan pendekatan komprehensif di sekolah umum mampu memberikan pandangan dan pemahaman baru terhadap siswa tentang perbedaan dan keharmonisan hidup dalam masyarakat plural. Pendidikan ini bertujuan untuk mengenalkan berbagai ajaran agama tentang penghormatan, perdamaian, toleransi dan kemanusiaan.

Maka untuk itu Madrasah sebagai institusi pendidikan Islam yang mencerdaskan dan mempribadikan anak didik, perlu mempersiapkan siswanya bukan saja dengan ilmu agama tetapi juga ilmu umum, yang dalam pembelajarannya telah dilakukan secara pendekatan yang digunakan harus bersifat integralistik yang menyangkut semua dimensi dan ranah pembelajaran sehingga waktu yang ada dapat digunakan secara efisien dan mendapatkan hasil yang optimal. Selain itu Madrasah perlu juga membekali siswanya

45 Suzanne Rosenblith dan Bea Bailey, "Comprehensive Religious Studies in Public Education : Educating for a Religiously Literate Society," Jurnal dari Educational Studies (American Educational Studies Association) 42 No 2 (2007), 9-111, http://vnweb.hwwilsonweb.com/hww/result/getResult.jhtml/_DARG= 
suatu kompetensi atau keahlian guna sebagai bekal baginya setelah lulus. Untuk mencapai hal itu, maksimalisasi manajemen berbasis sekolah sangat diperlukan. ${ }^{46}$

Konsep pendidikan integrated learning, joyfull learning, dan cooperatif learning kiranya perlu diterapkan dalam manajemen pengajaran di Madrasah dengan guru yang professional sebab Slavin mengatakan guru yang baik adalah yang menguasai materi pelajaran, memiliki keterampilan pedagogis, yang selalu mengajar secara efektif dengan penuh semangat, menyenangkan dan perhatian dalam tugasnya, memutuskan persoalan dengan menggunakan psikologi pendidikan. ${ }^{4}$

Visi Madrasah juga mesti diperbaharui dengan menggunakan slogal populis, Islami, berkualitas, serta mandiri. Kemudian perlunya mendirikan Madrasah berbasis standar (Nasional/Internasional) mengingat madrasah banyak memiliki kekurangan dalam berbagai aspek. Meski demikian dewasa ini umat Islam telah memiliki madrasah yang berprestasi dan bereputasi baik semisal Insan Cendikia di Serpong Banten, MIN Malang. Kemudian Madrasah pembangunan UIN Jakarta yang siap bersaing di era modern.

\section{Penutup}

Dari paparan di atas dapat disimpulkan pendidikan Islam pada Madrasah mengalami tantangan modernisasi. Modernisasi yang terjadi terjadi pada abad 19 hingga saat ini telah membawa perubahan yang cukup kompleks terhadap berbagai aspek bidang kehidupan termasuk pendidikan Islam di Madrasah. Di era modern

\footnotetext{
${ }^{46}$ Lihat Hasbi Indra, Pendidikan Islam Melawan Globalisasi (Jakarta : Rida Mulia, 2005), h.202-210.

${ }^{47}$ Robert E. Slavin, Educational Psychology Theory and Practice (Massachusetts : Allyn and Bacon, 1994), h. 24.
} 
pendidikan Islam di madrasah dan lembaga pendidikan Islam justru dituntut lebih profesional dan bukan dikelola sekedar asal-asalan, sebab masyarakat dewasa ini telah mengalami perubahan orientasi dengan mengedepankan rasionalitas. Untuk itu upaya merekosiliasi ajaran agama dan era modern perlu dilakukan kaum Muslimin khususnya di Madrasah. Hal ini untuk menunjukkan citra Islam sesuai dan tidak bertentangan dengan era modern sebagaimana Barat tuduhkan. Usaha ini penting dilakukan sebab di era modern ini kehidupan manusia akan ditandai oleh dua kecendrungan yang saling bertentangan/berlawanan dengan Islam yakni; iptek vs imtak, ajaran vs sekulerisasi serta spiritual vs material. Untuk mengatasi hal itu lembaga pendidikan Madrasah harus meningkatkan peranannya sebagai lembaga pendidikan Islam yang handal yang dapat merespon dan mengantisipasi dampak negatif dari kemajuan modern saat ini, misalnya dengan merevitalisasi sistem pendidikannya sehingga dapat meningkatkan kualitas pembelajaran, kemudian mempersiapkan lulusan madrasah yang handal dan siap pakai sehingga dapat menyeimbangi arus modern yang ada dan tidak ketinggalan zaman dengan tidak meninggalkan program pendidikan madrasah yang menjadi kekhasan atau keunggulan institusi pendidikan Islam yang sudah ada sejak dahulu.

\section{Pustaka Acuan}

Abdullah, Ibrahim, Suparman, Ma'had Aly, Profil Pendidikan Tinggi Pondok Pesantren di Indonesia, Yogyakarta : RDI Indonesia.

Al-Attas, Naquib, Muhammad, Syed, Islam and Seculerisme, Kuala Lumpur : Muslim Youth Movement of Malaysia, 1979.

Ashrohah, Harun, Sejarah Pendidikan Islam, Jakarta : PT. Logos Wacana Ilmu, 2001, Cet. Ke-2.

Azra, Azyumardi, Esei-esei Intelektual Islam, Jakarta : PT. Logos Wacana Ilmu, 1998, Cet. Ke-1. 
Azra, Azyumardi, Modernisasi Pendidikan Islam dan Epistemologi Ilmu, Makalah pada peringatan 70 tahun Pondok Modern Gontor, 31 Agustus 1996

Binder, Leonard, Islamic Liberalism, Chicago : The Universirty of Chicago Press, 1988.

Chapra, M. Umar Islam dan Tantangan Ekonomi Islamisasi Ekonomi Kontemporer, Surabaya : Risalah Gusti, 1999, Cet. Ke-1.

Esposito, John L. (ed), The Oxford Encyclopedia of the Modern World, London : Oxford University Press, 1995, Vol. 2.

Khayyal, Karîm, Abdul, Muhammad, Syarh wâ Tahlîl Ushûl al-Isyrîn, Dâr al-Dakwah, Iskandariâh, Cairo, tt.

Kurzman, Charles, (ed), Modernist Islam 1840-1940; A Source Book, Oxford: Oxford University Press, 2002.

Madjid, Nurcholish, Bilik-Bilik Pesantren Sebuah Potret Perjalanan, Jakarta : Paramadina, 1997, Cet. Ke-1.

, Masyarakat Religius dan Dinamika Industrialisasi dalam Islam. Kemodernan dan keindonesiaan, Bandung : Mizan, 1987.

Masud, Khalid, Muhammad"Religius Identity and Mass Education", dalam Johan H. Meuleman (ed), Islam in the Era Globalization, Muslim Attitudes Towards Modernity and Identity, Jakarta : INIS, 2001.

Mastuhu, Memberdayakan Pendidikan Islam, Jakarta : Logos Wacana Ilmu, 1999.

Muhaimin, et.al., Paradigma Pendidikan Islam Upaya Mengefektifkan Pendidikan Agama Islam di Sekolah, Bandung : PT. Remaja Rosdakarya, 2004.

Nasution, Bakti, Hasan, Filsafat Umum, Jakarta : Gaya Media Pratama, 2001.

Nasichah, Da'wah Pada Masyarakat Modern Problem Kehampaan Spiritual, Jakarta : Da'wah : Jurnal Kajian Da'wah dan Budaya, Vol. X No 2. Desember 2003.

Nasution, Harun, Perlunya Menghidupkan Kembali Pendidikan Moral, Jakarta : Konsorsium Pendidikan Agama di Perguruan Tinggi Umum, DIKTI Depdikbud, 1995.

Noer, Deliar, Gerakan Modern Islam di Indonesia 1990-1942, Jakarta : LPE3S, 1980. 
Peraturan Pembinaan Madrasah dalam Rangka Otonomi Daerah, Depag RI : Dirjen Pembinaan Kelembagaan Agama Islam, 2001.

Putro, Suadi, Muhammad Arkoun, Tentang Islam dan Modernitas, Jakarta : Paramadina, 1998, Cet. Ke-1.

Qomar, Mujamil, Pesantren dan Transformasi Metodologi Menuju Demokratisasi Institusi, Jakarta : Eralngga, tt.

Rahim, Husni, Arah Baru Pendidikan Islam di Indonesia, Jakarta : Logos Wacana Ilmu, 2001.

Rahman, Fazlur, Islam and Modernity, Transformation of an Intellectual Tradition Chicago: The University of Chicago Press, 1982.

Rochaety, Eti, Rahayuningsih Yanti, Gusti, Prima, Pontjorini Sistem Informasi Manajemen Pendidikan, Jakarta : Bumi Aksara, 2006, Cet. Ke-11.

Rosenblith, Suzanne dan Bailey, Bea, "Comprehensive Religious Studies in Public Education : Educating for a Religiously Literate Society," Jurnal Educational Studies (American Educational Studies Association) 42 No 22007

Syam, M. Noor, Filsafat Pendidikan dan Dasar Filsafat Pancasila, Surabaya : Usaha Nasional, 1988.

Tahir, Tarmidzi, Umat Islam dan Tantangan Dunia Modern, (Center For Moderate Muslim Indonesia), Diakses Lewat Internet Pada Tanggal 23 Juli 2008.

Tim Perumus Fakultas Teknik Universitas Muhammadiyah Jakarta, Al-Islam dan IPTEK, Jakarta, Universitas Muhammadiyah Jakarta, 1998.

Wahid, Abdurrahman, Agama dan Modernisasi adalah Satu", dalam majalah Komunikasi Ekaprasetia Pancakarsa, No. 40/tahun $\mathrm{VI} / 1985,47$. 